JPH: Jurnal Pembaharuan Hukum

Volume 8, Number 3, December 2021

\title{
THE DISCOURSE ON IMPLEMENTATION OF PROGRESSIVE LAW IN RECOVERING STATE LOSSES DUE TO CRIMINAL ACTS OF CORRUPTION
}

\author{
Yopi Gunawan \\ Universitas Singaperbangsa, Karawang, Indonesia \\ yopigunawan573@gmail.com
}

\begin{abstract}
The number of corruption cases in Indonesia that are not appropriately resolved is the cause of the emergence of progressive laws. Public trust in the law began to fade because the applicable law did not determine many problems. The law is not seen as a solution provider, and it becomes a particular problem for law enforcement. This article aims to analyze the concept of recovering state losses due to corruption through the implementation of progressive law. The method used is normative legal research using a qualitative approach. This article concludes that progressive law enforcement to eradicate criminal acts of corruption lies in harmonizing the values contained in society and then realizing those values into reality, where their application is influenced by several factors, including legal substance, legal structure, culture law, professionalism, and leadership. The development of the modus operandi of corruption in hiding assets resulting from corruption encourages the urgency of implementing a progressive law enforcement strategy by implementing 2 (two) strategic steps, namely: a) Taking rule-breaking actions in the form of seizure of the defendant's assets to guarantee payment of state losses; b) The judge gives a Contra Legem decision in the form of an obligation to pay replacement money without a subsidiary which is preceded by confiscation of the guarantee so that it will close the defendant's room to escape from paying replacement money.
\end{abstract}

Keywords: Asset; Corruption; Law; Losses; Progressive; Returns; State.

\section{A. INTRODUCTION}

The birth of the progressive legal concept initiated by Satjipto Raharjo because of his reflection at 60 years of age in Indonesia as the rule of law has not shown an extraordinary legal life. Progressive law was recognized in Indonesia in 2002. Due to the feeling of dissatisfaction with positive legal practices, progressive law enforcement was born. Advanced law appears as a solution to the failure of the application of positive law. Added to this is the concern of the Indonesian people in terms of the quality of law enforcers since the 1998 reform. Fundamentally, the law as an institution brings people to happiness, to live in prosperity, and to be fair. The quality of law can only be measured from its service to humans, and law is not an absolute and final institution ${ }^{1}$.

1 Sadjipto Rahardjo, Menggagas Hukum Progresif Indonesia, Pustaka Pelajar, Semarang, 2006, Page 34-38. 
Justice is an essential requirement for everyone, especially when it comes to legal matters. Because progressive law focuses on the needs of society, not on legal certainty, it certainly has its effects on criminal law, particularly on the principle of legality ${ }^{2}$. In direction, justice and legal certainty are the two elements that must be accommodated as public law, which has an essential role in protecting the interests of the public at large. Therefore, it becomes crucial to see whether progressive law has been articulated in favourable and future regulations.

Implementing the law is not always with a statutory approach but with dedication, empathy, determination, and commitment to the nation's problems, thereby producing creative solutions for the welfare of the people as formulated in the 1945 Constitution. At the level of enforcement, progressive legal movements are shown through the use of discretion or legal breakthroughs (role breaking) by progressive law enforcement agencies, who use their authority to protect the interests of the poor and marginalized. Laws at the regional and remote levels run creatively. Woodhouse $^{3}$ explained that law enforcers at the local level make matters outside their rigid job description. They make assignments more effective, settlement of cases faster and shorter while still based on existing laws.

Many cases of corruption in society are not resolved properly and cause the emergence of progressive laws. Corruption has now become the centre of international attention. The United Nations is seriously holding an international conference to discuss the issue of corruption. The UN Congress on The Prevention of Crime and the Treatment of Offender shows that the international community recognizes that bribery has been transnational. For Indonesia, the problem of corruption has become a problem that is quite difficult to overcome because it has spread to all aspects of public life, even the firm stance of law enforcers has not been effective in reducing the number of corruption crimes ${ }^{4}$. Currently, corruption is increasingly widespread, as reported in various media, even though various law enforcement efforts, both prevention and prosecution, have been carried out.

According to the research and development data of the KPK (Corruption Eradication Commission), it shows that during 2013-2016 the state loss due to corruption amounted to IDR 4,853,615,205,003, - (four trillion eight hundred and fifty-three billion six hundred fifteen million two hundred and five thousand and three rupiah) while those who were rescued were punished by the payment of replacement money of IDR $1,711,830,662,761$, - (one trillion seven hundred eleven billion eight hundred thirty million six hundred sixty-two thousand seven hundred and sixty-one

2 Muliadi, A., Peran Politik Hukum dalam Penegakan Hukum yang Berkeadilan, Jurnal Hukum Adil, Vol.2 No.2, 2011.

3 Sadjipto Rahardjo, Hukum Progresif: Hukum yang Membebaskan, Jurnal Hukum Progresif, Vol.1 No.1, 2005, page 1-24.

4 M. Beni Kurniawan, Problematika Pengisian Jabatan Pimpinan Komisi Pemberantasan Korupsi, Jurnal Kebijakan Hukum, Vol.12 No.2, 2018, page 138. 
rupiah). This means that the value of money that has succeeded in returning to the state treasury is much lower than the money lost due to corruption ${ }^{5}$.

Corruption is an act that uses power secretly to benefit oneself or others by abusing the power that is in itself. This criterion illustrates that corruption is a crime that law enforcers do not easily detect because it is carried out silently, thus requiring more extraordinary efforts to expose it. Disclosure of criminal acts of corruption in an institution/ministry, State and Regional Owned Enterprises, Regional Government is not necessarily able to snare the parties involved in the vortex of the case. It may not necessarily be able to recover state losses. It all depends on the techniques and tactics of law enforcement to prove the elements of corruption that exist in the perpetrators' actions ${ }^{6}$.

The specific strategy that needs to be pursued is to change the legal paradigm of the Police, Attorney General's Office, KPK and the Court to progressively punish, which not only prioritizes imprisonment but also needs to optimize the return of state losses through the confiscation of assets and criminal compensation money. For this reason, from the beginning of the investigation, law enforcement officers must prioritize the interests of recovering state losses (follow the money). Still, it should be noted that the practice of following the money must be carried out comprehensively by tracking all the suspect's assets abroad, considering that one of the inhibiting factors is not optimal refund of state losses due to the perpetrator storing assets abroad, for example in the Gayus Tambunan tax corruption case which caused losses to the state IDR 106.7 billion and U \$ D 18 million, of which only 2.081 billion was deposited into the state treasury. The rest has not been successfully returned and is suspected stored abroad ${ }^{7}$.

Indonesia's procedural law and judicial system have had a significant impact on the success of efforts to recover the proceeds of corruption. Perpetrators can take advantage of various loopholes in the legal system that result in them being able to escape sanctions to return assets resulting from corruption crimes. Enforcing progressive laws to recover state losses requires the courage of law enforcers to get out of the status quo that does not provide a sense of justice for the state as victims because law enforcement which has been running only carries out formal legal procedures that lead to traditional justice. At least 2 (two) reasons are urgent to apply progressive law in eradicating corruption. First, the perpetrators of crime have covered all groups and the increasingly varied modus operandi that conservative law enforcement methods can no longer overcome. Second, existing empirical data shows that there is a gap between state losses incurred and assets that have been returned state

5 Nandang Sambas., and Ade Mahmud, Model Penegakan Hukum Progresif Dalam Pengembalian Kerugian Negara Melalui Pidana Uang Pengganti, Lex Lata: Jurnal IImiah IImu Hukum, Vol.1 No.2, 2019, page 140-152.

6 Ismail Marzuki, Rekonstruksi Penegakan Hukum Dalam Upaya Pemberantasan Tindak Pidana Korupsi Di Indonesia, IN RIGHT: Jurnal Agama dan Hak Azazi Manusia, Vol.3 No.1, 2013, page 199-213.

7 M.Beni Kurniawan, Problematika Pengisian Jabatan Pimpinan Komisi Pemberantasan Korupsi, Jurnal Kebijakan Hukum, Vol.12 No.2, 2018, page 138. 
losses are much greater than the amount produced, indicating that law enforcers are lagging behind the criminal events that are their objects so that the legal paradigm that is applied is not sufficient apply the law legally which is rigid and rigid.

Many studies related to the concept and idea of recovering state losses due to corruption through the implementation of progressive law have provided reviews, including: first, Nandang Sambas and Ade Mahmud ${ }^{8}$ tried to review the advanced law enforcement model in returning state losses through criminal compensation. The results of his research are obstacles that affect the process of paying compensation for illegal money, including first, the Law c.q Article 18 paragraph (3) of the law on the Eradication of Criminal Acts of Corruption. Second, law enforcers do not immediately track, freeze and confiscate money/assets resulting from corruption. Third, the modus operandi of the perpetrators is through money laundering. The progressive law enforcement model to restore state losses is to change the paradigm of law enforcement that the appropriate criminal sanctions are sanctions that are oriented towards money/assets resulting from corruption (follow the money and asset recovery) by tracking, freezing, and confiscating of purchases resulting from criminal acts of crime since the investigation stage followed by a decision on the obligation to pay replacement money without subsidizing it with imprisonment so that it still imposes legal responsibility on the defendant to restore state losses.

Second, the idea conveyed by Ismail Marzuki ${ }^{9}$ with the theme of reconstructing law enforcement to eradicate corruption in Indonesia. This study concludes that the problem of crime occurs in developing countries such as Indonesia and often occurs in developed countries. That means corruption has become an international issue. Indonesia is one of the most corrupt countries in the world. Therefore, a rule/law regarding the crime was made, which has undergone several changes to cover the shortcomings that exist in the previous regulations. Likewise, law enforcement agencies continuously improve themselves to overcome corrupt behavior both internally and externally. However, in the realm of praxis, corruption is increasingly rampant. Therefore, progressive steps are needed with an integrated judicial system to apply a fair law to corruptors to achieve a welfare state.

Third, the research conducted by Bayu Setiawan ${ }^{10}$ with the theme of applying progressive law by judges to realize transcendent substantive justice concludes that Philosophy of Law underlies various legal theories and ideas, one of which is Progressive Legal thought. However, the progressive legal thinking of Satjipto Rahardjo's teachings has not entirely based the

8 Nandang Sambas., and Ade Mahmud, Model Penegakan Hukum Progresif Dalam Pengembalian Kerugian Negara Melalui Pidana Uang Pengganti, Lex Lata: Jurnal I/miah IImu Hukum, Vol.1 No.2, 2019, page 140-152.

9 Ismail Marzuki, Rekonstruksi Penegakan Hukum Dalam Upaya Pemberantasan Tindak Pidana Korupsi Di Indonesia, IN RIGHT: Jurnal Agama dan Hak Azazi Manusia, Vol.3 No.1, 2013, page 199-213.

10 Bayu Setiawan, Penerapan Hukum Progresif Oleh Hakim Untuk Mewujudkan Keadilan Substantif Transendensi, Jurnal Kosmik Hukum, Vol.18 No.1, 2018, page 33-53. 
views of lawmakers in Indonesia, so that the laws enforced in Indonesia are still partly a product of Dutch law, even rules created by Indonesia itself are still not based on progressive legal thinking, but most are still based on positivistic-legalistic review.

Fourth, research was conducted by Efraim Mbomba Reda, I Nyoman Putu Budiartha, I Made Minggu Widyantara ${ }^{11}$ on the progressive legal conception in regulating corruption in Indonesia. This study concludes that in the current Draft Criminal Code, advanced law has been held, precisely in Article 2 paragraphs (1) and (2). Progressive law is also regulated in Act No. 48 of 2009 concerning Judicial Power. Then, the actualization of advanced law in the regulation of criminal acts of corruption in Indonesia is that judges with their powers consider the sociological context of a society in making decisions. Judges, prosecutors, and lawyers can certainly discuss together in eradicating corruption. Efforts were also made to reconstruct and redefine the powers of law enforcement. This arrangement can also encourage the KPK to be more progressive in eradicating corruption and build law enforcers who have morality to become role models and increase community participation, for example, by forming NGOs in preventing and fighting corruption in various agencies.

Fifth, research was conducted by Yanto Sufriadi ${ }^{12}$ on the application of progressive law in law enforcement amid a democratic crisis. This study concludes that globalization has resulted in economic inequality and widespread poverty. Poverty will hurt democracy. In situations of elitist legislation, applying laws based on the legal-positivism tradition will further expand injustice and poverty. Therefore, amid an arrogant legislation product situation, progressive application of the law is an alternative that is more likely to achieve justice and people's welfare. Court practice in Indonesia shows the development of advanced ways of applying the law, but the legal-positivism tradition is still mainstream for judges.

The primary difference between the five previous studies and this research is that this study succeeded in formulating 2 (two) strategic steps in the urgency of implementing progressive law in the return of assets resulting from corruption, namely: a) Performing rule-breaking actions in the form of confiscation of the defendant's assets to guarantee payment of losses country; b) The judge gives a Contra Legem decision in the form of an obligation to pay replacement money without a subsidiary, which is preceded by confiscation of collateral so that it will close the space for the defendant to be free from paying the replacement money. This study also concludes that progressive law enforcement to eradicate corruption lies in aligning the values contained in society and then realizing those values into reality. Its application is influenced by several factors, including legal substance, structure, culture, law, professionalism, and leadership.

11 Efraim Mbomba Reda., I Nyoman Putu Budiartha., I Made Minggu Widyantara, Konsepsi Hukum Progresif Dalam Pengaturan Tindak Pidana Korupsi Di Indonesia, Jurnal Interpretasi Hukum, Vol.1 No.2, 2020, page 35-39

12 Yanto Sufriadi, Penerapan Hukum Progresif dalam Penegakan Hukum di tengah Krisis Demokrasi, Jurnal Hukum, Vol.17 No.2, 2010, page 233-248. 
The problem of returning assets has recently become an interesting issue in the legal repertoire of corruption eradication, which has prompted law enforcement institutions to issue technical regulations to regulate the procedures for returning assets. For this reason, the issue of the problem of purchases resulting from corruption and progressive law enforcement strategies is interesting to discuss in this article.

\section{B. RESEARCH METHODS}

This research is a normative legal research or library research method, where the technique or method used in this research is by examining existing legal materials. To obtain information from various aspects of the issue that is being sought answers, the approach used in this research is the statute approach ${ }^{13}$. Types and sources of data used in this research are primary, secondary and tertiary legal materials. Primary legal materials, namely legal materials that have binding power, include basic norms or rules (Preamble to the 1945 Constitution), basic regulations (Body of the 1945 Constitution), statutory regulations, and others. Secondary legal materials are legal materials that explain primary legal materials, such as academic texts, draft laws, and others. Tertiary legal materials are legal materials that explain primary and secondary legal materials, such as dictionaries, encyclopedia, and others. Data and information are collected through library research and legal documentation to obtain primary legal materials, secondary legal materials, and tertiary legal materials relevant to the problems studied. Preliminary data and secondary data obtained through this research activity will be identified according to certain objective groups, then analyzed qualitatively, and then presented descriptively by describing, explaining, and describing according to the problems in this study.

\section{RESULTS AND DISCUSSIONS}

\section{Actualization of the Concept of Progressive Law in Regulating Corruption in Indonesia}

Progressive law requires wise and creative law enforcers to work on it because the key to change lies in the contextual interpretation of the law. The community indeed expects law enforcers who consider the certainty of rules in a sociological context. In the application of progressive law in court to eradicate criminal acts of corruption, of course, it varies ${ }^{14}$. First, judges with their powers can consider the social context of a society in making decisions. Second, judges, prosecutors and lawyers can certainly discuss together related to criminal acts of corruption committed by individuals and make decisions with the motivation to provide social justice for all Indonesian people for the realization of Pancasila in the life of the nation and state.

Apart from judicial power, the power to enforce the law is also the duty and authority of the police and prosecutors. This means that to enforce the law is the joint authority of the three institutions. Therefore,

13 Zainuddin Ali, Metode Penelitian Hukum, Sinar Grafika, Jakarta, 2011, page 21-24. 14 Sadjipto Rahardjo, Op.cit, page 1-24. 
creating conditions in which law enforcement agencies become independent, integral institutions under one auspice is challenging. Article 8 of Act No. 2 of 2002 concerning the Police explains that the police are under the auspices of the executive branch, not the judiciary ${ }^{15}$. Likewise, the prosecutor's office is under executive power; therefore, it tends to be quickly intervened by interested parties.

Consequently, it is necessary to reconstruct and redefine the power of law enforcers. The KPK has enormous authority and is even said to be a super body to eradicate corruption. The KPK has the authority to take over investigations, investigations, and prosecutions carried out by the police and prosecutors. This granting of great authority is the state's effort to support the KPK in eradicating corruption. With such great power, we certainly hope that the KPK can take progressive actions in eradicating corruption in the country. Acting right, being responsible, transparent, intelligent in thinking are traits that a leader must possess. Law enforcement agencies must have leaders who possess these characteristics. Thus it can be a role model for many people $^{16}$. There are, of course, various roles that society can play in eradicating corruption, among other things, campaigning for the spirit of anti-corruption, improving moral education, knowledge, participating in overseeing the government. If supervision is not carried out, corruption will occur.

The community is expected to play a role in supervision. For example, in making regulations. Anticipating the emergence of multiinterpretive rules that can be used by a group of people for a particular interest, the making of these regulations must be guarded as best as possible. The following parts that the community must monitor our government operational activities. The monitoring method can be done with a network system, forming an NGO. If the network system or NGOs are spread across government agencies, then people can think again about committing corruption.

\section{Progressive Law as a Legal Paradigm in Eradicating Criminal Acts of Corruption in Indonesia}

As the legal principles contained in various legal theories or legal schools, progressive law initiated by Satjipto Rahardjo also has the main focus, namely "law is for humans and not the other way around, and the law does not exist for itself, but for something broader, namely for human dignity, happiness, prosperity, and human glory ". Progressive law also departs from the basic assumption that law is not a final institution because the law is always in the process of being (law as a process, law in the making). To illustrate that law is always a process,

15 M. Beni Kurniawan, Problematika Pengisian Jabatan Pimpinan Komisi Pemberantasan Korupsi, Jurnal Kebijakan Hukum, Vol.12 No.2, 2018, page 138.

16 Abdul Fatakh, Kejahatan Pidana Khusus Korupsi Di Indonesia Perspektif Hukum Islam Progresif Dalam Integritas Hukum Nasional, Al-Mizan, Vol.11 No.1 2015, page 15-32. 
Satjipto Rahadjo ${ }^{17}$ describes it very interesting as follows: "Law is an institution that continually builds and transforms itself towards a better level of perfection. The quality of perfection here can be verified into the factors of justice, welfare, concern for the people and others. This is the essence of law that is always becoming (law as a process, law in the making). Law does not exist for the law itself, but for humans".

A more progressive law enforcement is needed, namely law enforcement that requires pro-people and achieves substantive justice in its application where proper law enforcement is. Just law enforcement, fair law enforcement is law enforcement that provides protection and great benefits for each person and the seeker of justice himself. The extent to which the understanding of the meaning and implementation of law enforcement will significantly determine the actual image of the law in society.

Thus, there are many things related to law enforcement issues. If we observe the elements in the system, we will find several influencing factors, such as the substance of laws and regulations, structure, and legal culture. Observations of a more academic nature are necessary, but practice in the field shows that this problem is complex. In principle, the meaning of supervision and observation is very different. So it is better if the understanding is separated between supervisors and observers so that there is no wrong interpretation. Although we have to hope, for example making perfect laws and regulations, satisfying income for judges and a culture that supports a political climate, in reality, law enforcement by the courts is very dependent on the extent to which the decisions made by the judges have thoughtfully applied the principle of justice ${ }^{18}$.

The application of the principle of justice and other legal attributes used by judges as the basis for implementing the law can be realized by determining a legal basis following the values of justice adhered to by society. In the context of law enforcement, of course, it cannot be separated from the legal system as a whole. Legal principles (Rechts beginsellen) are one part of the rule of law. Yasser S. Wahab, Julianto J. J. Kalalo, Lisa Mery, (2015) Lawrence Meier Friedman (1977) divides the elements of the legal system into three, namely structure, substance, and legal culture ${ }^{19}$. Apart from the three factors above, according to Romli Atmasasmita ${ }^{20}$, professionalism and leadership are also included in the legal system. This is an element of the ability and personal skills of law enforcement figures. Professionalism itself can be defined as

17 Sadjipto Rahardjo. Op.cit, page 1-24.

18 Yanto Sufriadi, Penerapan Hukum Progresif dalam Penegakan Hukum di tengah Krisis Demokrasi, Jurnal Hukum, Vol.17 No.2, 2010, page 233-248.

19 Muhammad Irwan., Slamet Sampurno Soewondo., and Julianto Jover Jotam Kalalo, Hukum Progresif Sebagai Paradigma Hukum Dalam Pemberantasan Tindak Pidana Korupsi Di Indonesia, SOCIETAS: Jurnal IImu Administrasi Dan Sosial, Vol.7 No.1, 2018, page 38-46.

20 Romli Atmasasmita, Tiga Paradigma Hukum dalam Pembangunan Nasional, Jurnal Hukum Prioris, Vol.3 No. 1, 2012, page 31-32. 
someone who makes an (activity, activity, effort, and job) that is done for (income or pleasure) or gives (contributes) by relying on high (expertise, skills, or proficiency) by involving personal commitment (moral) deep. A law enforcement position is not just a vocation but also a profession.

Leadership is also a less critical factor; choosing the right and clean leader is a progressive step. Because a clean, moral, fair, honest and faithful leader will generate authority towards the subordinates, who are led to become obedient, reluctant to follow the leader's example. A good leader can hold on to the mandate; what he says is what he says, and what he does is what he says. Such a leader is far from ambitious, not arbitrary, does not wear and does not work sincerely, works solely for religious worship, does not enrich himself by corrupting and does not seek praise from anyone. So only because of carrying out the work as a good and beneficial for others. In short, the leader must have excellent and universal traits such as acting correctly, responsibly, transparently, and smartly in thinking.

Thus in every law enforcement agency such as the KPK, prosecutors, police, judiciary, and all elements of government must have leaders who have the characteristics as above and then can become role models for the individuals they lead. For this reason, it is deemed necessary and very urgent in choosing the leader of an agency. It must be genuinely objective in assessing, not based on emotional closeness alone. In this case, the community must also carry out its function, namely to supervise and contribute to creating a conducive and happy legal condition. KPK was formed based on Article 43 paragraph (1) of Act No. 20 of 2001 concerning Amendments to Act No. 31 of 1999 concerning Eradication of Corruption Crime. The legal basis for this commission is Act No. 30 of 2002 concerning the Corruption Eradication Commission $^{21}$.

From the scope of duties and powers, the KPK has quite general duties and violence, both in terms of investigations, investigations and prosecutions, and the taking over of authority from other agencies related to eradicating corruption. The scope of duties, as stipulated in Article 6 of the Corruption Eradication Commission Law, includes 1) Coordination with other agencies authorized to eradicate corruption; 2) Supervision of agencies authorized to eradicate corruption; 3) Conducting investigations, investigations and prosecutions of criminal acts of corruption; 4) Take action to prevent criminal acts of corruption, and 5) Monitoring of state government officials.

In the criminal justice system based on KUHAP (Criminal Procedure Code), it is determined that investigators are police officers (Article 6 paragraph [1] KUHAP), public prosecutors are prosecutors (Article $13 \mathrm{KUHAP}$ ), and judges are stated judicial officials (Article 1 point $8 \mathrm{KUHAP}$ ), all law enforcement officers in above is under the agency or

21 M. Syamsudin, Kecenderungan Paradigma Berfikir Hakim dalam Memutus Perkara Korupsi. Jurnal Media Hukum, Vol.15 No.2, 2008, page 202. 
institution, each of which stands alone as described in the previous section. Meanwhile, according to Act No. 30 of 2002 concerning the KPK, institutionally, both investigators, prosecutors and judges (ad hoc) are under the commission because they are appointed by the commission (Article 45 paragraph [1], 51 paragraph [1], 56 section [1] of the KPK Law). According to Article 53 of Act No. 30 of 2002, for trial examination in court, this commission has a special court for corruption cases where the KPK files the prosecution. This court is under the environment of the general court. Not only is the KPK an institution that deals explicitly with corruption, but the community's contribution is very much needed. The public must take part because of two things; namely, the people must be aware that corruption has a broad impact on society. In this case, the community is the victim of a criminal act of crime, and the community is the main component of the state.

Eddy O.S. Hiariej ${ }^{22}$ states that role is a system of rules that contains behavioural standards at specific positions in society. Individuals or private groups can hold functions, the part of the role holders can be appropriate or may be opposite with what is specified in the rules, as for the strategic roles of society in efforts to eradicate corruption, including creating awareness of the spirit of anti-corruption, participating and playing an active role in every anti-corruption campaign, increasing moral education and knowledge and participating in overseeing the government. Lack of supervision or ineffective supervision is a supporting condition for corruption. Therefore, it is hoped that the community will take part in the management.

The first supervision is the supervision of making regulations. The making of rules must be guarded so that grey rules do not appear to be used by a group of people for their benefit. The second supervision is the supervision of the implementation of regulations or government operational activities. Supervision can be done through a network system, by forming an NGO, or individually. With an invisible but scattered network system in government agencies, people think several times about committing corruption. The formation of NGOs such as Transparency International Indonesian (TII), Indonesian Transparency Society, Indonesian Corruption Watch and so on are also instrumental in assisting government oversight. Indonesian Corruption Watch (ICW) is currently one of the most outspoken independent institutions in the anticorruption movement.

Together with the community, ICW seeks to increase the capacity of the public to claim their rights to obtain basic facilities guaranteed by the state without being corrupted. Another problem faced by nongovernmental organizations, one of which is ICW, is the demand for basic facilities that have been guaranteed by the state where NGOs need clear regulations made by the government as the legitimacy of nongovernmental organizations in demanding their fundamental rights to be able to carry out their functions effectively so that they can help

22 Eddy O.S. Hiariej, Pengembalian Aset Kejahatan, Jurnal Opinio Juris, Vol.13, 2013, page 2-3. 
government eradicating corruption, this is one of the concrete efforts to strengthen $\mathrm{NGOs}^{23}$.

\section{Progressive Law Enforcement Strategies to Return the Proceeds of Corruption Crimes}

Indonesia is a rich country, but there are still many people who live below the poverty line. The question that arises is whether there is corruption or corruption due to poverty. Poverty is not in line with the concept of the rule of law (rechstaat) and welfare state adopted by Indonesia. All the country's wealth, both socio-economically and culturally, is the principal capital in enhancing the nation's development towards a developed country and providing tangible benefits to all Indonesian people. Indonesia should become a developed and prosperous country with a variety of abundant natural resources and potential resources ${ }^{24}$. However, looking at the social facts, many Indonesians live below the poverty line.

This fact shows that the abundant natural wealth is not directly proportional to the prosperity of the people; the wealth of the state is only enjoyed by a handful of government elites. This situation often creates antipathy towards a group of people who benefit. Corruption, collusion, and nepotism are one of the causes of the low level of prosperity of the Indonesian people and the problem of mismanagement of natural wealth. The corruption that occurs in all lifelines has made the state budget aimed at building infrastructure, health, education not on target or has been misused. As one of the obstacles to national economic growth, corruption eradication needs to be carried out progressively so that it has a significant effect on the return of assets resulting from corruption $^{25}$.

Progressive law enforcement emphasises the aspect of prevention and prosecution by saving the losses of the corrupted state. As an economic crime, in practice, it does not only involve public officials but business people, legislators and other parties who are seen as needing each other. This situation illustrates that corruption is not just a legal issue but has turned into a culture that involves various dimensions and professions. This crime-handling strategy requires extraordinary law enforcement to get an effective result. Corrupt acts will not disappear only with suggestions and lectures in places of worship. Various efforts and models of guidance to prevent corruption have been tried, but none have shown satisfactory results in lowering the corruption index.

The phenomenon of corruption, which is detrimental to state finances and has violated the social and economic rights of the

23 Bayu Setiawan, Penerapan Hukum Progresif Oleh Hakim Untuk Mewujudkan Keadilan Substantif Transendensi, Jurnal Kosmik Hukum, Vol.18 No.1, 2018, page 33-53.

24 M. Yasin al-Arif, Penegakan Hukum dalam Perspektif Hukum Progresif, Undang: Jurnal Hukum, Vol.2 No.1, 2019, page 169-192.

25 Efraim Mbomba Reda., I Nyoman Putu Budiartha., I Made Minggu Widyantara, Konsepsi Hukum Progresif Dalam Pengaturan Tindak Pidana Korupsi Di Indonesia, Jurnal Interpretasi Hukum, Vol.1 No.2 edition 2020, page 35-39. 
community, has prompted various groups, including legal academics, to think of specific efforts and strategies to eradicate corruption from multiple aspects as a preventive and repressive measure. Thus, decomposition must be carried out in an extraordinary way. Law enforcement to tackle corruption crimes can now be done through a progressive legal approach ${ }^{26}$.

The emergence of the concept of progressive law is not an accident. Advanced law is a never-ending truth-seeking process. The central idea of advanced law is "law for humans". This assumption is the initial justification that law exists not for itself but for human life. The concept of progressive law in seeking the truth is based on the empirical reality that exists in society. Progressive legal discourse that starts from the assumption of law is for humans and is always in the process of becoming, with consequences in every explanation, it will see the views of other legal theories. Starting from the perspective that law is for humans, law enforcers should not apply the law according to the law because they are not mouthpieces. Progressive law emphasizes law enforcers to uplift the value of justice that is behind favourable law regulations by thinking and acting creatively in the name of social justice and rejecting the status quo that does not respond to society's demands ${ }^{27}$.

Law enforcers must prioritize honesty and concern for the difficulties of people who are victims of corrupt behaviour. Pro Justitia actions must be oriented not only to legal certainty but also to the legal interests of the directly affected people. The focus of law enforcers in the context of progressive law is not only on written rules but also on the social realities. It demands creativity to enforce responsive laws according to the right time and place. The progressiveness of law enforcement is characterized by responsive ways of thinking and acting without having to wait for reasonable regulations because the central point of progressive law is not on the rules but law enforcers. Thus, progressive law enforcers can bring justice to society even with inadequate regulations ${ }^{28}$. Why is the focus of attention on law enforcers, not on regulations, because progressive legal views believe that legal problems often occur because there is a gap between regulations (dass sollen) and public behaviour (das sein), regulations regarding corruption are a criminal law response to overcome if there is a gap. This means that the state has prepared criminal sanctions in the event of cracks in the behaviour of state administrators with the applicable legal rules.

The reality of law enforcement on corruption cases so far has not shown seriousness in reversing state losses because it can be seen from the very procedural/rigid way of law that only follows regulations as a

26 Ade Mahmud, Urgensi Penegakan Hukum Progresif Untuk Mengembalikan Kerugian Negara Dalam Tindak Pidana Korupsi, Masalah-Masalah Hukum, Vol.49 No.3, 2020, page 256-271.

27 A.M. Mujahidin, Hukum Progresif: Jalan Keluar dari Keterpurukan Hukum di Indonesia, Varia Peradilan, Vol.XXII No.257, 2007.

28 Ahmad Zaenal Fanani, Hermeneutika Hukum Sebagai Metode Penemuan Hukum dalam Putusan Hakim, Varia Peradilan, Vol. XXV No.297, 2010 
manifestation of formal law and does not show an orientation towards justice, not to mention the problem of abusing conspiring law enforcement authorities. With the perpetrators of corruption adding to the grim portrait of corruption eradication, law enforcers who should be at the forefront are involved in the vortex of corruption. The impact is that efforts to eradicate corruption cannot run as expected and do not solve the core problem, namely punishing the perpetrators and returning state losses. The idea of substantive justice, in reality, is still conceptual and far from the truth ${ }^{29}$.

The main problem that must be the primary concern of eradicating corruption is that the government, through law enforcement needs to formulate a law enforcement strategy that causes a deterrent effect and restores state losses to be utilized for the greatest prosperity of the nation. Law enforcers need to strive for progressive law enforcement from the stage of investigating, prosecuting and imposing court decisions oriented towards the interests of the wider community. The advanced legal discourse offered by Satjipto Rahardjo ${ }^{30}$ seeks to fight for justice that is waiting for the people and encouraging law enforcers to not punish by using classical conventional methods that do not benefit society. It is time for law enforcers to be at the forefront of corruption eradication using creative ways that dare to break the rule of law (rulebreaking) which is seen as not reflecting social justice. Theoretically, the principle of "law for humans" for progressive law becomes the basis, entrance and point of view (point of view) to encourage law enforcers to work creatively based on social justice as the ultimate goal to be achieved $^{31}$. Based on the concept of progressive law, legal breakthroughs that can be done are:

First, performing rule breaking actions in the form of confiscation of assets. The first step in applying progressive laws to recover the proceeds of corruption is to carry out confiscations. According to Ade Mahmud ${ }^{32}$, confiscation is a follow-up part of the investigation process in the criminal justice system to take over and place objects under the control of investigators for the sake of proof. Meanwhile, a seizure is an act by the prosecutor to transfer ownership of objects that are made, used or resulted from a criminal act based on a court decision that is legally binding so that the authors consider confiscation and seizure two terms that have different juridical consequences. It is said differently because when an object is confiscated, the suspect still has the owner's status even though he physically does not control it, while confiscation has legal consequences for the transfer of property status from the defendant to the state Carry out a confiscation because generally, the

29 Ade Mahmud, Urgensi Penegakan Hukum Progresif Untuk Mengembalikan Kerugian Negara Dalam Tindak Pidana Korupsi, Masalah-Masalah Hukum, Vol.49 No.3, 2020, page 256-271.

30 Sadjipto Rahardjo, Op.cit, page 1-24.

31 Dey Ravena, Wacana Konsep Hukum Progresif Dalam Penegakan Hukum Di Indonesia. Jurnal Wawasan Hukum, Vol.23 No.02, 2010, page 155-156

32 Ade Mahmud, Urgensi Penegakan Hukum Progresif Untuk Mengembalikan Kerugian Negara Dalam Tindak Pidana Korupsi, Masalah-Masalah Hukum, Vol.49 No.3, 2020, page 256-271. 
objects that are the object of confiscation and confiscation are the same. Ade Mahmud assesses that efforts to seize assets have not been fully maximized because, in the investigation process, investigators cannot confiscate all assets that are suspected to be the result of corruption because they have already been transferred to a third party (disguised) or stored abroad so that they are not entirely traceable. Regarding objects that can be confiscated by Act No. 31 of 1999 in conjunction with Act No. 20 of 2001 concerning the Eradication of Corruption, it does not regulate in detail so that investigators are still using the provisions of Article 39 paragraph (1) of the Criminal Procedure Code that the objects that can be confiscated are: 1) Movable or immovable objects belonging to the suspect/defendant that are suspected of being the result of a criminal act; 2) Objects of a suspect/defendant, whether partially or completely, should be allegedly obtained from a criminal act; 3) Objects in any form that are used or prepared to commit a criminal act; 4) Objects prepared or used by the suspect/defendant to obstruct the judicial process; 5) objects specially made to be used to commit a criminal act, and; 6) Objects that have a direct relationship/connection with a criminal act.

Second, performing Contra Legem actions. In practice, it appears that judges in handling corruption cases tend to follow a positivistic paradigm, and there are still few judges with progressive penalties as initiated by Satjipto Rahardjo. This legal-positivist concept is still the mainstream paradigm among Corruption Eradication Judges. The strength of this legal-positivism way of thinking in the realm of praxis has implications for the judge's decision in recovering state losses, especially the penalty for compensation money ${ }^{33}$. Whenever the decision on the obligation to pay compensation to the convict is passed, the tendency that occurs is that the judge will open up subsidiary space for the defendant to replace it with imprisonment, which is more beneficial to the convict but will harm the state because the potential for recovering state losses can be lost. Such a verdict is legally acceptable as an alternative if the convict is genuinely unable to pay it. However, the tendency that has occurred so far is that convicts are financially able to pay replacement money, which prefers to serve a relatively short and more economical prison sentence.

As a result, there was a failure to save the state's money from the corruptors. In the end, the judge's decision was unable to achieve the goal of the punishment, which should have a deterrent effect and be a means of correction for the convicted person to realize his mistake. This failure needs to be addressed utilizing progressive law that offers a new paradigm in law that has been dominated by legal positivism. The importance of advanced law is based on the experience of bringing corruptors to account for their actions in court, especially to compensate

33 H.A. Malthuf Siroj., and Ismail Marzuki, Penegakan Hukum Progresif: Upaya Mewujudkan Keadilan Substantif, HAKAM, Vol.1 No.2, 2017, page 237-260 
for state losses ${ }^{34}$. This failure was caused by submissive nature to the completeness of existing laws, such as existing procedures, doctrines and regulations. As a result, the law has become a haven for corruptors. The traditional way of going to rule is that the possibility of recovering losses is so tiny that it is seen as counter-progressive law enforcement.

The strengthening of the legal positivism mindset among Indonesian judges is the leading cause of corruptors apart from the obligation to compensate for state losses. Thus, this paradigm of thinking needs to be changed by encouraging judges to become more familiar with and produce progressive decisions. The Contra Legem verdict is realized with a penalty of substitute money without providing a subsidiary criminal alternative to close the space. The convict does not escape from the obligation to compensate the state. Still, such a decision must be preceded by confiscation of collateral against the convict's assets during the investigation process to guarantee repayment of replacement money, as explained in the first point. The Contra Legem decision is in the hands of the judge as to the case decision-maker. Still, in its implementation, it must be supported by a progressive law carried out by the Prosecutor's Office and the KPK as investigators in the form of seizure of the convict's property, whether related or not related to the criminal act of corruption. In general, both the Attorney General's Office and the KPK investigators always carry out confiscations. Still, as previously explained, the value of confiscated assets tends to be smaller than the state's losses ${ }^{35}$.

Therefore, before making a Contra Legem decision, the judge must ensure that the value of the confiscated assets of the accused must be greater than the loss of the state or at least have the same value so that the state losses can be returned in full, that is why investigators must have the courage to confiscate the assets even though they are not related with a corruption case. Thus, implementing a progressive law enforcement strategy in recovering state losses requires synchronization and the imbalance between the criminal justice sub-system starting from the investigation process to court decisions and the position of judges' decisions being the spearhead in implementing progressive law.

\section{CONCLUSION}

The implementation of progressive law in the effort to eradicate criminal acts of corruption lies in the activity of aligning the values contained in society and then making those values into reality, wherein its application is influenced by several factors, including legal substance, legal structure, legal culture, professionalism, and leadership. Corruption is a criminal act that is categorized as an extraordinary crime due to the extensive impact of corruption, which concerns the welfare of the people, so the KPK as a law

34 Hwian Christianto, Penafsiran Hukum Progresif Dalam Perkara Pidana, Mimbar Hukum, Vol.23 No.3, 2011, page 431-645.

35 Imelda F.K. Bureni, Kekosongan Hukum Perampasan Aset Tanpa Pemidanaan, MasalahMasalah Hukum, Vol.45 No.4, 2016, page 297. 
enforcer must also carry out more progressive and massive prevention and prosecution efforts to minimize. It has even completely eradicated this nation's problem, namely corruption. In this case, too, the KPK does not work alone. It also requires an active role of the community in making preventive efforts to create an anti-corruption society. The development of the modus operandi of corruption in hiding assets resulting from criminal acts encourages the urgency of implementing a progressive law enforcement strategy by implementing 2 (two) strategic steps, namely: a) carrying out rule-breaking actions in the form of seizure of assets related to or not related to the criminal act of corruption. as a guarantee for the return of state assets unless the defendant can prove the origin of the support obtained from a legitimate business; b) The judge gives a Contra Legem decision in the form of an obligation to pay replacement money without a subsidiary which is preceded by confiscation of the guarantee so that it will close the defendant's room to escape from paying replacement money.

\section{BIBLIOGRAPHY}

\section{Books:}

Sadjipto Rahardjo, 2006, Menggagas Hukum Progresif Indonesia, Pustaka Pelajar, Semarang;

Zainuddin Ali, 2011, Metode Penelitian Hukum, Sinar Grafika, Jakarta;

\section{Journals:}

A.M. Mujahidin, Hukum Progresif: Jalan Keluar dari Keterpurukan Hukum di Indonesia, Varia Peradilan, Vol.XXII No.257, 2007;

Abdul Fatakh, Kejahatan Pidana Khusus Korupsi Di Indonesia Perspektif Hukum Islam Progresif Dalam Integritas Hukum Nasional, Al-Mizan, Vol.11 No.1, 2015;

Ade Mahmud, Urgensi Penegakan Hukum Progresif Untuk Mengembalikan Kerugian Negara Dalam Tindak Pidana Korupsi. Masalah-Masalah Hukum, Vol.49 No.3, 2020;

Ahmad Zaenal Fanani, Hermeneutika Hukum Sebagai Metode Penemuan Hukum dalam Putusan Hakim, Varia Peradilan, Vol. XXV No.297, 2010;

Bayu Setiawan, Penerapan Hukum Progresif Oleh Hakim Untuk Mewujudkan Keadilan Substantif Transendensi, Jurnal Kosmik Hukum, Vol.18 No.1, 2018;

Dey Ravena, Wacana Konsep Hukum Progresif Dalam Penegakan Hukum Di Indonesia. Jurnal Wawasan Hukum, Vol.23 No.02, 2010;

Eddy O.S. Hiariej, Pengembalian Aset Kejahatan, Jurnal Opinio Juris, Vol. 13 2013,

Efraim Mbomba Reda., I Nyoman Putu Budiartha., I Made Minggu Widyantara, Konsepsi Hukum Progresif Dalam Pengaturan Tindak Pidana 
Korupsi Di Indonesia, Jurnal Interpretasi Hukum, Vol.1 No.2 edition 2020,

H.A. Malthuf Siroj., and Ismail Marzuki, Penegakan Hukum Progresif: Upaya Mewujudkan Keadilan Substantif, HAKAM, Vol.1 No.2, 2017,

Hwian Christianto, Penafsiran Hukum Progresif Dalam Perkara Pidana, Mimbar Hukum, Vol.23 No.3, 2011,

Imelda F.K. Bureni, Kekosongan Hukum Perampasan Aset Tanpa Pemidanaan, Masalah-Masalah Hukum, Vol.45 No.4, 2016;

Ismail Marzuki, Rekonstruksi Penegakan Hukum Dalam Upaya Pemberantasan Tindak Pidana Korupsi Di Indonesia, IN RIGHT: Jurnal Agama dan Hak Azazi Manusia, Vol.3 No.1, 2013;

M. Beni Kurniawan, Problematika Pengisian Jabatan Pimpinan Komisi Pemberantasan Korupsi, Jurnal Kebijakan Hukum, Vol.12 No.2, 2018;

M. Syamsudin, Kecenderungan Paradigma Berfikir Hakim dalam Memutus Perkara Korupsi, Jurnal Media Hukum, Vol.15 No.2, 2008;

M. Yasin al-Arif, Penegakan Hukum dalam Perspektif Hukum Progresif, Undang: Jurnal Hukum, Vol.2 No.1, 2019;

Muhammad Irwan., Slamet Sampurno Soewondo., and Julianto Jover Jotam Kalalo, Hukum Progresif Sebagai Paradigma Hukum Dalam Pemberantasan Tindak Pidana Korupsi Di Indonesia, SOCIETAS: Jurnal IImu Administrasi Dan Sosial, Vol.7 No.1, 2018;

Muliadi, A, Peran Politik Hukum dalam Penegakan Hukum yang Berkeadilan. Jurnal Hukum Adil, Vol.2 No.2, 2011;

Nandang Sambas., and Ade Mahmud, Model Penegakan Hukum Progresif Dalam Pengembalian Kerugian Negara Melalui Pidana Uang Pengganti. Lex Lata: Jurnal I/miah I/mu Hukum, Vol.1 No.2, 2019;

Romli Atmasasmita, Tiga Paradigma Hukum dalam Pembangunan Nasional, Jurnal Hukum Prioris, Vol.3 No. 1, 2012;

Sadjipto Rahardjo, Hukum Progresif: Hukum yang Membebaskan, Jurnal Hukum Progresif, Vol.1 No.1, 2005;

Yanto Sufriadi, Penerapan Hukum Progresif dalam Penegakan Hukum di tengah Krisis Demokrasi, Jurnal Hukum, Vol.17 No.2, 2010. 